\title{
THE GREAT INDIAN BUSTARD ARDEOTIS NIGRICEPS (VIGORS) IN AND AROUND THE ROLLAPADU WILDLIFE SANCTUARY, ANDHRA PRADESH, INDIA
}

\author{
K. Thulsi Rao ${ }^{1}$ and S.M. Maqsood Javed ${ }^{2}$ \\ ${ }^{1}$ Assistant Conservator of Forests, ${ }^{2}$ Research Assistant, Ecological Research \& Monitoring Laboratories, Nallamalai Hill Ranges, Eastern \\ Ghats, Project Tiger Circle, Srisailam, Kurnool District, Andhra Pradesh 518102, India \\ E-mail: thulsirao@yahoo.co.in
}

web supplement

\begin{abstract}
The Great Indian Bustard Ardeotis nigriceps (Vigors), an threatened bird species of Indian sub-continent, now, is struggling for survival in fragmented patches of drier areas of the country. Rollapadu Wildlife Sanctuary in Andhra Pradesh is one such fragmented repository established for the conservation of bustard and its associated species of the region. Initially the population of bustard was found to be increasing due to the zealous protection from the Forest Department. But this infatuated protection of the habitat gradually led to the disuse by the bustards especially during summer breeding season (April-June). On the other hand, conversion of grasslands adjoining the sanctuary into farmlands resulted in discontinuous distribution within a decade of time. Reconnaissance survey conducted between January to December 2003 in 12 sites from where the bustard was known, it was found only from five sites. The population of Great Indian Bustard estimated by us ranges between 30-37. The present paper reports an account of estimated population size during non-breeding and breeding season, nesting sites and adverse impact of associated species and other factors in and around the Rollapadu Wildlife Sanctuary.
\end{abstract}

\section{KEYWORDS \\ Ardeotis nigriceps, Great Indian Bustard, Monitoring, Rollapadu Wildlife Sanctuary}

The Great Indian Bustard Ardeotis nigriceps (Vigors) is a bird of open spaces of scanty grassland interspersed with scrub and cultivation in more or less semi-desert country (Ali \& Ripley, 1969). The Great Indian Bustard (GIB) - an endemic species found in parts of the Indian subcontinent, is a threatened avian species. It is included in Schedule-I of the Wildlife (Protection) Act, 1972, and about 13 sanctuaries have been established for its protection (Rahmani, 1987, 1989). One of these is the Rollapadu Wildlife Sanctuary in Kurnool district of Andhra Pradesh, which was established in the year 1988. This area harbours many grassland species including the flagship species, the GIB, which is known as Battameka Pakshi in Telugu (Thulsi Rao, 2002).

In 2003, the Andhra Pradesh Forest Department launched the "Bustard Monitoring Project". The aim of the project is to know about the status and distribution of bustard population, including the factors which are creating adverse impact on it, in and around the Rollapadu Wildlife Sanctuary.

\section{Study Area}

The Rollapadu Wildlife Sanctuary $\left(15^{\circ} 45^{\prime} \mathrm{N}-78^{\circ} 22^{\prime} \mathrm{E}\right)$ with its rolling grasslands is situated $18 \mathrm{~km}$ southeast of Nandikotkur town of Kurnool District on Nandikotkur - Nandyal Road (Fig.
1). The Grassland ecosystem of this sanctuary represents a mosaic of diversified flora and fauna. Flora includes grasses like - Aristida funiculata, Chrysopogon fulvus, Heteropogon contortus, Sehima nervosum and Dicanthium pseudoischaemum. This habitat is also dotted with scattered medium vegetation and Phoenix sp. is seen along the seasonal stream beds (Images 1-4 ${ }^{\mathrm{w}}$ ). The fauna comprises many species of avifauna, reptiles and mammals like Blackbuck, Wolf, Indian fox, Jungle cat, etc.

Topography is of gentle undulating plains with an elevation of $290 \mathrm{~m}$. Generally, the vegetation is of the southern tropical thorn forest type (Champion \& Seth, 1968). Climate, in general, is hot and dry for most part of the year. However, November to February is pleasant. The mean annual temperature of the area is around $28^{\circ} \mathrm{C}$. The hottest months are April and May, with temperatures soaring up to $42^{\circ} \mathrm{C}$. December is the coldest month with temperature falling well below $18^{\circ} \mathrm{C}$. The average annual rainfall is $450 \mathrm{~mm}$. But the rainfall is erratic and is unevenly distributed. Though the pre-monsoon shower sets in the month of May, southwest monsoon when majority of the rainfall occurs is from June to September.

\section{Materials And Methods}

In the recent past the GIB was reported from Banaganapalli, Nellibanda, Peddapadu, Siruvella, Palakurti, and Molagavalli in Kurnool district (Manakadan \& Rahmani, 1989). Reconnaissance survey conducted between January to December 2003 in 12 sites from where the bustard was known indicated its presence in only five sites. On the basis of frequent sighting of bustards, the following five sites were selected (Fig. 2) for monitoring: (i) Rollapadu Wildlife Sanctuary (Plot-1, 2 and 3), (ii) Vipangandla - Byrapuram crop fields, (iii) Alaganur Baraka - Parumanchala crop fields, (iv) Jalakanur - Sunkesula Gani Baraka and (v) Kypa - Pandlapuram crop fields (near Banaganapalli).

A team consisting of forest officials, experienced bird watchers and research assistants counted the birds in each flock at various sites during January to December 2003. All the activities of bustards, individuals or flocks, during foraging and breeding periods were very keenly monitored (Image $6^{\mathrm{w}}$ ) twice a day (morning and evening) with the help of binoculars and spotting scope. Special efforts like deploying of one bird watcher exclusively for each site was ensured to monitor bustards during overcast and rainy days as bustards have a tendency to flock

w See Images 1-9 in the web supplement at www.zoosprint.org

(C) Zoo Outreach Organisation; www.zoosprint.org Manuscript 1326; Received 31 January 2005; Revised received 01 September 2005; Finally accepted 25 September 2005 ; Date of publication 21 October 2005 November 2005 | ISSN 0973-2535 (Print edition); 0973-2551 (Online edition) 


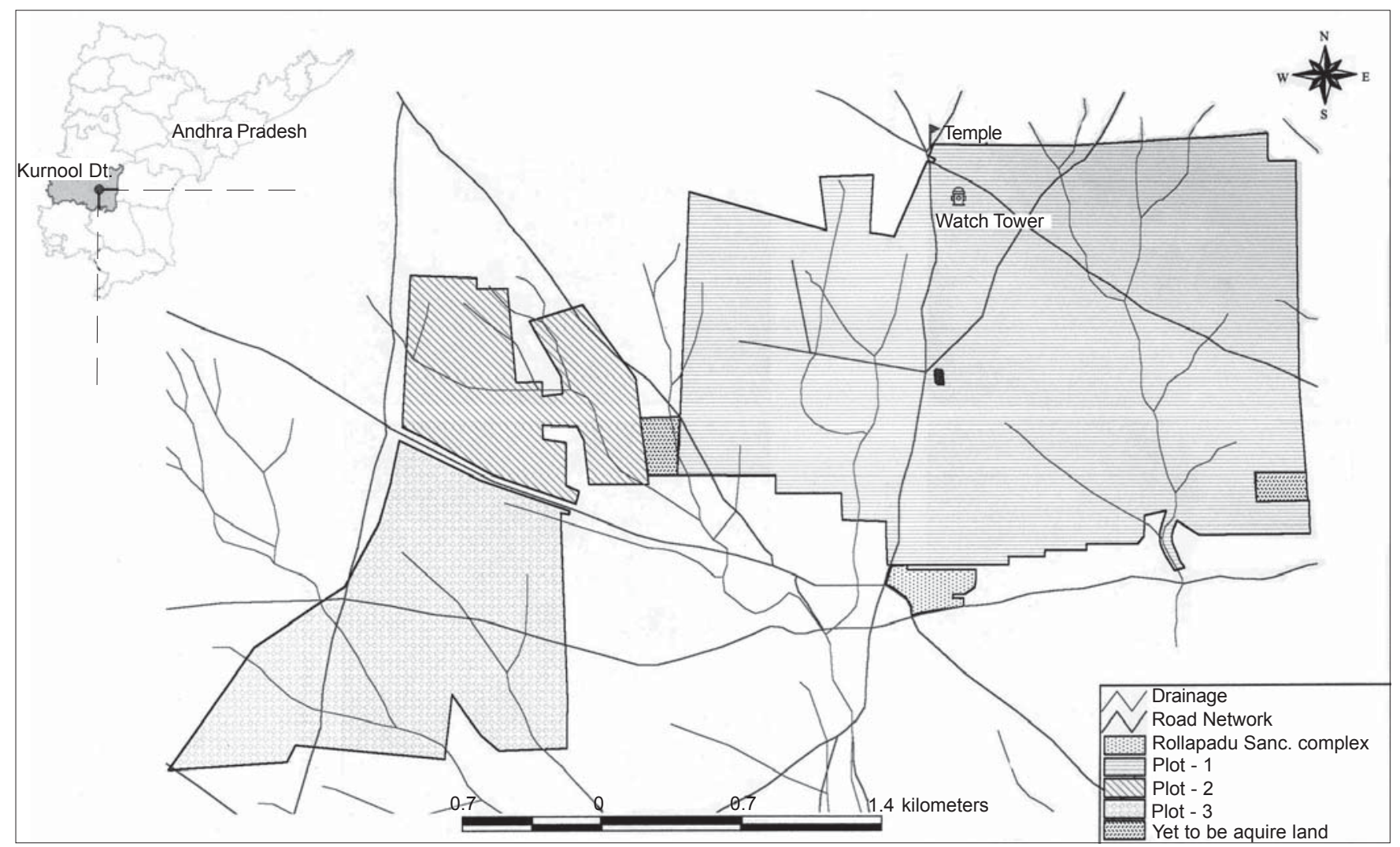

Figure1. Map showing the study area - Rollapadu Wildlife Sanctuary

in large numbers immediately after heavy rains (Manakadan \& Rahmani, 1986).

Nests were located by walking through the study area. Once a female bustard is flushed out, she flies or runs away, moving very rapidly with her neck extended and head low. The female bustard tries to maintain a sufficient distance from the nest, thereby making it difficult for an intruder to spot the nest. In this situation, the birdwatcher moved back at least 300 to $400 \mathrm{~m}$ from the assumed nest location, and a binocular or spotting scope was used to observe the female from the watch tower or tree (Image $5^{\mathrm{w}}$ ). After the female had returned to the nest and the nest location was precisely defined, another person was guided to the nest by the observer. Once the nest was found, its accurate location was determined using a thin, small wooden pole peg with a colour band on its top.

\section{Observations and Results}

Non-breeding season (January-March, 2003):

Generally, during this season bustards prefer to forage in flocks in harvested crop fields, as well as open grazing lands within and outside the Rollapadu Sanctuary. But only two or three females (separately) were observed foraging inside, until the onset of the breeding season (i.e. last week of March or first week of April). During this season we observed 27 bustards, including two adult males (Table 1).
Breeding season (April-December, 2003):

About 30-37 bustards, including two males (1 sub-adult \& 1 adult) were seen during the breeding season (Table 1) and the number was not much different with that of the non-breeding season. It is observed that bustards generally avoid foraging inside the sanctuary. They are seen in open grasslands adjoining the sanctuary for foraging as well as for breeding (Image $6^{\mathrm{w}}$ ). They move into the sanctuary from July onwards. During peak breeding season (September - November) 10-14 females along with one sub-adult and one displaying territorial male were sighted. May be, all of these migrated locally from the adjoining grasslands of the sanctuary for breeding.

During the study period, about 28-35 female bustards (Table 1) and their nesting site details were recorded (Tables $2 \& 3$ ). Twenty-one nests/eggs were located in total $(60-75 \%$ of breeding success), out of which 10 hatched (hatching success - 47.61\%) (Images 7-9w). Jungle Crow predated on two eggs and Indian Fox on five eggs, while one egg was trampled by cattle, one egg was found infertile and two eggs were deserted. Overall $52.39 \%$ of eggs failed to hatch. In the month of April, three nests were located outside the sanctuary in an open dry stony strewn grasslands (Image $7^{\mathrm{w}}$ ), with less vegetation and about 10 female bustards were sighted. Along with this, three new breeding grounds were recorded, i.e., AlaganurParumanchala, Jalakanur - Sunkesula and Puppinut Chenlu (near Gani) and five nests were located very close to the thickly vegetated seasonal streams inside the sanctuary (Table 3). 
Flock composition:

A flock of 35 bustards was sighted at the Rollapadu in 1984 while it was drizzling (Ali \& Rahmani, 1984). A few days later, on another rainy day, the staff of the Forest Department saw 38 bustards in the same area. Similarly in July, 1986, a flock of 10 to 17 males were seen for two weeks (Manakadan \& Rahmani, 1986). The biggest flock now seen during non-breeding season (2003) is of five bustards ( $2 \mathrm{M} \& 3 \mathrm{~F})$ which were observed for about four weeks in the harvested crop fields of Vipangandla Bairapuram locality. But during breeding season males get separated and the flock has only 2 to 3 female bustards (Table 1). Recent study recorded only two males during non-breeding season in separate localities. While during breeding season out of these two males, only one male was displaying in and outside the sanctuary and nothing is known about the other male.

Adverse impacts on bustard population

The egg and chick of bustards have many predators like wolf, jungle crow, fox, jackal, monitor lizard and mongoose. During the incubation period and one-and-a-half-month of fledgling time (approximately) is the most crucial period in the life of a bustard. Once the chick is able to fly, it can escape most of its natural enemies. The adult bustard is quite capable of confronting a fox, a jackal or a monitor lizard (Rahmani \& Manakadan, 1989).

Generally Blackbuck is one of the main associated species of the GIB. The present monitoring study indicates $800+$ Blackbucks in and around this sanctuary, which is beyond its

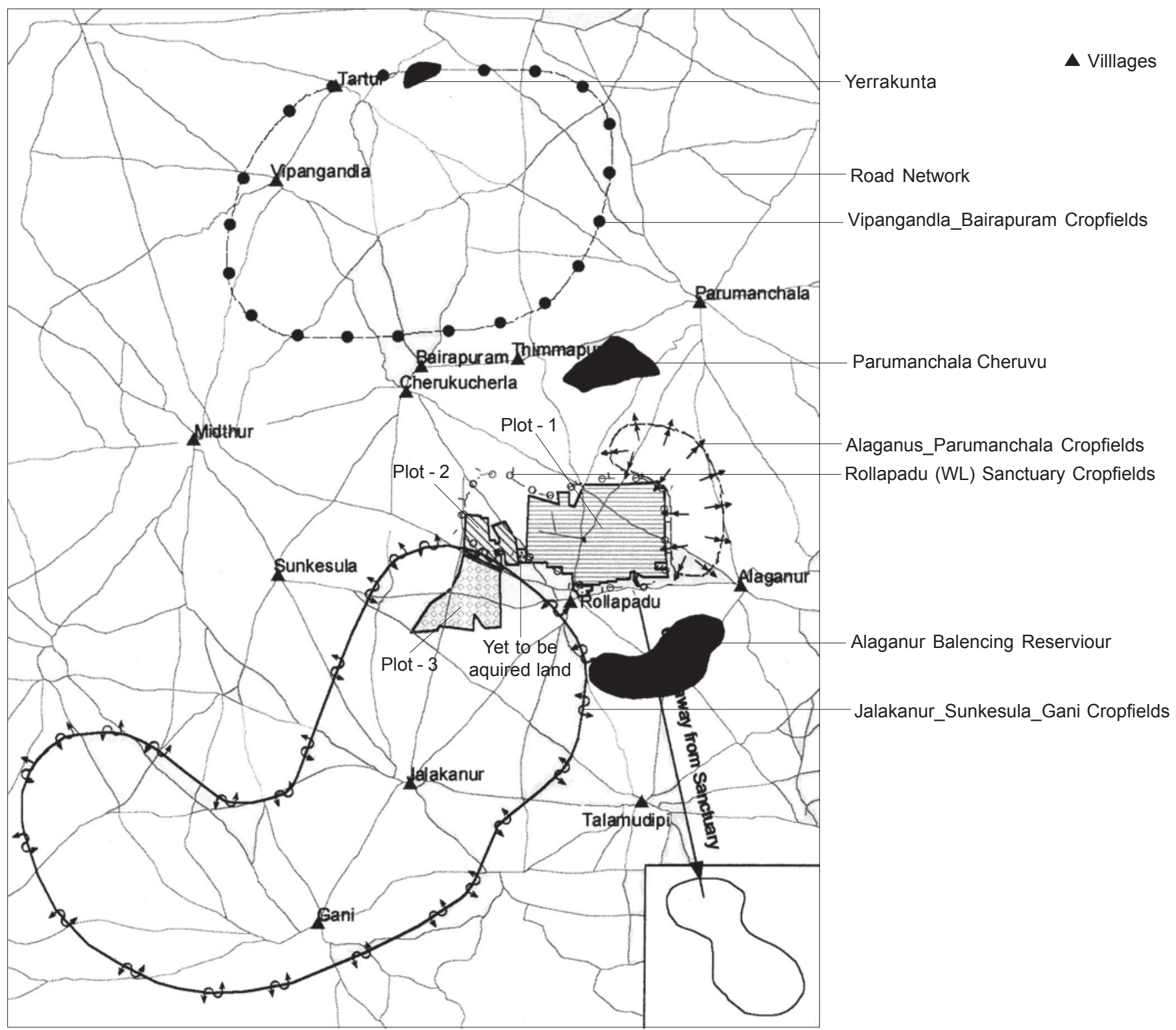

Figure 2. Map showing five selected bustard monitoring sites in and around Rollapadu Wildlife Sanctuary 
carrying capacity. Due to regular crop raiding by the Blackbuck, complaints from the farmers are frequent. Their ire is redirected to the bustard and the sanctuary in general. Crop damage by Blackbuck around the sanctuary is of a serious nature and could worsen if measures to combat this problem are not taken immediately (Manakadan \& Rahmani, 1989).

Along with natural predators and associated species impact, another insidious enemy of the bustard is livestock. The livestock while grazing reach near the incubating bustard and disturbs it. This usually leads to unsuccessful incubation or temporary abandoning of the egg. That is the time when the egg is likely to be accidentally trampled upon by the livestock. If the egg is left unattended for long periods during summer, there may be a chance that the embryo will die due to direct exposure to the sun. Due to the above factors, about $52.39 \%$ of eggs failed to hatch during the study period.

\section{Discussion}

Earlier records indicated about 100-150 bustards in Andhra Pradesh (including Kurnool, Anantapur, Ranga Reddy \& Mahboobnagar districts) and about 100 bustards were estimated in 1985-88 in the Rollapadu grasslands of Kurnool district (Rahmani, 1989). However, the recent monitoring study estimated only about 30-37 bustards, a clear decline in the bustard population in and around Rollapadu Wildlife Sanctuary. The reasons behind this decline are over-grazing, human disturbance, increase in Blackbuck numbers resulting in resentment by villagers, and mismanagement of habitat. During our study, we located a few eggs in the early part of the month (April) of the breeding season and noticed change in the selection of nesting sites during peak breeding season. Earlier studies indicated the eggs were mostly located in the month of May and onwards (Manakadan \& Rahmani, 1985-86). The present study reveals that bustards are laying eggs within and outside the sanctuary.
During the study, it was really significant to notice alarming factors like small flock size, only a few displaying males and extent of adverse impact of associated species in and around the sanctuary. Continuous monitoring of existing bustard population will provide baseline data for taking up long-term studies on population trends, migration, distribution, habitat preference and habitat destruction.

\section{RECOMMENDATIONS}

1. Conserve and manage the habitat suitable for the GIB through scientific and administrative inputs.

2. Monitor the populations of GIB in and outside the sanctuary. 3. Management of Blackbuck populations through ecological measures.

4. Explore the possibilities of captive breeding.

5. Map the potential bustard areas around Rollapadu and neighboring districts.

6. Integrate the socio- economic development of people affected by the wildlife sanctuary, with that of the management of the GIB through eco-development programmes.

7. Create awareness among the local people about the importance of protecting the habitat and foraging grounds.

8. Study the migration movement of GIB through satellite tracking.

\section{REFERENCES}

Ali, S. and A.R. Rahmani (1984). Study of ecology of certain Endangered Species of Wildlife and their Habitats: The Great Indian Bustard. Bombay Natural History Society. Annual Report 2, 100pp.

Ali, S. and S.D. Ripley (1969). Handbook of the Birds of India and Pakistan. Oxford University Press, Bombay.

Champion, H.G. and S.K. Seth (1968). A Revised Survey of the Forestry Types of India. Government of India Press, New Delhi.

Manakadan, R. and A.R. Rahmani (1986). Study of Ecology of certain Endangered Species of Wildlife and their Habitat: The Great Indian Bustard. Bombay Natural History Society. Annual Report 3, 50pp. Manakadan, R. and A.R. Rahmani (1989). Rollapadu Bustard Sanctuary, with special reference to the Great Indian Bustard. Journal of the Bombay Natural History Society 86: 368-380.

Table 1. Population status of Great Indian Bustard (2003) in and around Rollapadu Wildlife Sanctuary.

\begin{tabular}{|c|c|c|c|c|c|c|c|c|c|}
\hline \multirow[t]{2}{*}{ SNo. } & \multirow[t]{2}{*}{ Monitoring Sites } & \multicolumn{2}{|c|}{$\begin{array}{l}\text { Non-breeding } \\
\text { Number of } \\
\text { bustard } \\
\text { sighted }\end{array}$} & \multirow[t]{2}{*}{$\begin{array}{l}\text { Season } \\
\text { Flock Size } \\
\text { (only largest } \\
\text { flock } \\
\text { mentioned) }\end{array}$} & \multicolumn{3}{|c|}{$\begin{array}{l}\text { Breeding } \\
\text { er of } \\
\text { rd sighted }\end{array}$} & \multirow{2}{*}{$\begin{array}{l}\text { ason } \\
\text { Flock Size } \\
\text { (only largest } \\
\text { flock } \\
\text { mentioned) }\end{array}$} & \multirow[t]{2}{*}{ Habitat Preference } \\
\hline & & M & $\mathbf{F}$ & & M & $\mathbf{F}$ & C & & \\
\hline 1 & Rollapadu Wildlife Sanctuary & - & 3 & 1 & 2 & $10-14$ & 9 & $\begin{array}{l}3(2 \mathrm{~F}, 1 \\
\text { subadult } \mathrm{M})\end{array}$ & $\begin{array}{l}\text { Grasslands with undulated terrain, thick } \\
\text { vegetation along the seasonal streams. }\end{array}$ \\
\hline 2 & Vipangandla - Byrapuram & 2 & 6 & $\begin{array}{l}5(3 \mathrm{~F} \\
2 \mathrm{M})\end{array}$ & - & 6 & - & $3(F)$ & $\begin{array}{l}\text { Crop fields with few patches of grassland, less } \\
\text { vegetation on the bunds. Plain terrain with some } \\
\text { undulated area. }\end{array}$ \\
\hline 3 & Alaganur - Parumanchala & - & 4 & 2 & - & 5 & 1 & 2 & $\begin{array}{l}\text { Grassland with few crop fields and less } \\
\text { vegetation near the streams, undulated terrain. }\end{array}$ \\
\hline 4 & Jalakanur - Sunkesula - Gani & - & 10 & 4 & - & 5 & - & 2 & $\begin{array}{l}\text { Grassland with scattered shrubs and less } \\
\text { vegetation near the seasonal streams, undulated } \\
\text { terrain. }\end{array}$ \\
\hline \multirow[t]{2}{*}{5} & Kypa - Pandlapuram & - & 2 & 2 & - & $2-5$ & - & 2 & Crop fields with no grassland, undulated terrain \\
\hline & $\begin{array}{l}\text { Total } \\
\text { Grand Total }\end{array}$ & 2 & $\begin{array}{l}25 \\
27\end{array}$ & & 2 & $\begin{array}{l}28-35 \\
30-37\end{array}$ & 10 & & \\
\hline
\end{tabular}

$\mathrm{F}=$ Female, $\mathrm{M}=$ Male, $\mathrm{C}=$ Chick 
Table 2. Nesting details of Great Indian Bustard (2003) in and around Rollapadu Wildlife Sanctuary.

\begin{tabular}{|c|c|c|c|c|c|}
\hline S.No & $\begin{array}{l}\text { Nest / Egg } \\
\text { (N/E) Code }\end{array}$ & $\begin{array}{l}\text { Egg Located } \\
\text { on }\end{array}$ & Nesting Site & Habitat Preference & Results/Remarks \\
\hline 1 & N/E-01(03) & 15.iv.03 & Alaganur Baraka* & Open, plain, stone strewn waste land. & Preyed by Indian Fox on 30.iv.03 \\
\hline 2 & N/E-02(03) & 23.iv.03 & $\begin{array}{l}\text { Jalakanur - Sunkesula } \\
\text { Baraka* \# }\end{array}$ & $\begin{array}{l}\text { Open, undulated waste land, besides } \\
\text { gravel mound. }\end{array}$ & $\begin{array}{l}\text { Deserted after } 33 \text { days of incubation from the } \\
\text { date of location. }\end{array}$ \\
\hline 3 & N/E-03(03) & 25.iv.03 & Alaganur Baraka* & Open, plain, stone strewn waste land. & $\begin{array}{l}\text { About } 50 \mathrm{~m} \text { away from N/E- } 01(03) \text {. } \\
\text { Preyed by Indian Fox. Fractured shell pieces } \\
\text { found } 15 \mathrm{~m} \text { away from the nest. }\end{array}$ \\
\hline 4 & N/E-04(03) & 16.v.03 & $\begin{array}{l}\text { Alaganur Baraka - } \\
\text { Parumanchala crop } \\
\text { fields * \# }\end{array}$ & $\begin{array}{l}\text { Open grassland with highly undulated } \\
\text { terrain, about } 14 \mathrm{~m} \text { away from the crop field. }\end{array}$ & Hatched and chick was sighted on 06.vi.03. \\
\hline 5 & N/E-05(03) & 01.vi.03 & Taggu Baraka & $\begin{array}{l}\text { Open plain grassland. Height of grass } \\
\text { around the nest about } 15 \mathrm{~cm}\end{array}$ & Hatched on 09.vi.03 and chick found dead. \\
\hline 6 & N/E-06(03) & 08.viii.03 & Mitta Baraka & $\begin{array}{l}\text { Open grassland. Height of the grass } \\
\text { around the nest about } 15 \mathrm{~cm}\end{array}$ & $\begin{array}{l}\text { Preyed by Indian Fox on } 27 . v i i i .03 \text {. Seen the } \\
\text { fractured shell pieces. }\end{array}$ \\
\hline 7 & N/E-07(03) & $05 . i x .03$ & Gantal Bedu & $\begin{array}{l}\text { Open grassland. Height of the grass } \\
\text { around the nest about } 10-15 \mathrm{~cm}\end{array}$ & Preyed by Indian Fox on 12.ix.03. \\
\hline 8 & N/E-08(03) & $06 . i x .03$ & Gantal Bedu & $\begin{array}{l}\text { Open grassland. Height of the grass } \\
\text { around the nest about } 10-15 \mathrm{~cm}\end{array}$ & $\begin{array}{l}\text { Preyed by Indian Fox on } 21 . i x .03 \text { seen the } \\
\text { fractured shell pieces, } 10 \mathrm{~m} \text { away from the } \\
\text { nest }\end{array}$ \\
\hline 9 & N/E-09(03) & 11.ix.03 & Taggu Baraka & $\begin{array}{l}\text { Open, dense grassland. Very close to the } \\
\text { stream possessing thick vegetation, near } \\
\text { the check dam. Height of grass around the } \\
\text { nest about } 30-40 \mathrm{~cm}\end{array}$ & Trampled by cattle on 22.ix.03 \\
\hline 10 & N/E-10(03) & 12.ix.03 & Mitta Baraka & $\begin{array}{l}\text { Open grassland, very close to the stream, } \\
\text { possessing thick vegetation. Height of the } \\
\text { grass around the nest about } 15-20 \mathrm{~cm}\end{array}$ & $\begin{array}{l}\text { Found infertile \& putrefied on } 04 . x .03 \text {. Even } \\
\text { though bustard was incubating. }\end{array}$ \\
\hline 11 & $\mathrm{~N} / \mathrm{E}-11(03)$ & 14.ix.03 & Taggu Baraka & $\begin{array}{l}\text { Open grassland, very close to the cart } \\
\text { track and lure crop. Height of the grass } \\
\text { around the nest about } 25-30 \mathrm{~cm}\end{array}$ & Damaged on 21.ix.03 by Jungle Crow. \\
\hline 12 & N/E-12(03) & $04 . x .03$ & Pade Baraka & $\begin{array}{l}\text { Open, dense grassland, very close to the } \\
\text { stream possessing thick vegetation, } \\
\text { Height of the grass around the nest } \\
\text { about } 60-70 \mathrm{~cm}\end{array}$ & $\begin{array}{l}\text { Hatched on } 20 . x .03 \text {, chick and shell pieces } \\
\text { seen at the nest. }\end{array}$ \\
\hline 13 & N/E-13(03) & $07 . x .03$ & Gantal Bedu & $\begin{array}{l}\text { Open, dense grassland, close to the } \\
\text { stream. Height of the grass around the } \\
\text { nest about } 50-60 \mathrm{~cm}\end{array}$ & $\begin{array}{l}\text { Hatched on } 30 . x .03 \text {, Chick was sighted along } \\
\text { with remaining of egg shell pieces at the nest. }\end{array}$ \\
\hline 14 & $\mathrm{~N} / \mathrm{E}-14(03)$ & $07 . x .03$ & Bail Padu & $\begin{array}{l}\text { Open, dense grassland, very close to the } \\
\text { stream with dense vegetation, near the } \\
\text { check dam. Height of the grass around } \\
\text { the nest about } 70-80 \mathrm{~cm}\end{array}$ & $\begin{array}{l}\text { Hatched on } 20 . x .03 \text {, chick and shell pieces } \\
\text { seen at the nest. }\end{array}$ \\
\hline 15 & N/E-15(03) & $07 . x .03$ & Taggu Baraka & $\begin{array}{l}\text { Open grassland, with scattered vegetation. } \\
\text { Height of the grass around the nest } \\
\text { about } 50 \mathrm{~cm}\end{array}$ & $\begin{array}{l}\text { Damaged on } 14 . x .03 \text { by Jungle Crow. Little } \\
\text { bit developed embryo was found inside the } \\
\text { egg. }\end{array}$ \\
\hline 16 & N/E-16(03) & 12.x.03 & Gantal Bedu & $\begin{array}{l}\text { Open, dense grassland, very close to the } \\
\text { stream with thick Phoenix sp. vegetation. } \\
\text { Height of the grass about } 50-60 \mathrm{~cm}\end{array}$ & $\begin{array}{l}\text { Hatched on } 03 . x i .03 \text {, chick and shell pieces } \\
\text { seen at the nest. }\end{array}$ \\
\hline 17 & N/E-17(03) & $29 . x .03$ & Watch Tower Plot & $\begin{array}{l}\text { Open, dense grassland with highly } \\
\text { scattered vegetation. Height of the grass } \\
\text { about } 70-80 \mathrm{~cm}\end{array}$ & $\begin{array}{l}\text { Hatched on } 20 . x i .03 \text {, chick and shell pieces } \\
\text { seen at the nest. }\end{array}$ \\
\hline 18 & N/E-18(03) & $31 . x .03$ & Taggu Baraka & $\begin{array}{l}\text { Open, dense grassland, undulated terrain } \\
\text { with very less or highly scattered } \\
\text { vegetation, except one Acacia nilotica tree } \\
\text { at about } 10 \mathrm{~m} \text { away from nest. Height of the } \\
\text { grass about } 70-80 \mathrm{~cm}\end{array}$ & $\begin{array}{l}\text { Hatched on } 14 . x i .03 \text {, chick and shell } \\
\text { pieces seen at the nest. }\end{array}$ \\
\hline 19 & N/E-19(03) & 17.xi.03 & $\begin{array}{l}\text { Puppinut Chenlu } \\
\text { (Situated between } \\
\text { Jalakanur and Gani)* \# }\end{array}$ & $\begin{array}{l}\text { Sunflower crop field with black cotton soil. } \\
\text { Crop height about } 1 \mathrm{~m}\end{array}$ & Deserted due to passerby disturbances. \\
\hline 20 & N/E-20(03) & 29.xi.03 & Bail Padu & $\begin{array}{l}\text { Open, dry grassland. Height of the grass } \\
\text { around the nest about } 10-15 \mathrm{~cm}\end{array}$ & $\begin{array}{l}\text { Hatched on 20.xii.03. Chick and shell pieces } \\
\text { seen at the nest. }\end{array}$ \\
\hline 21 & N/E-21(03) & 29.xi.03 & Gantal Bedu & $\begin{array}{l}\text { Open, dense grassland, adjoining to the } \\
\text { sanctuary boundary. Height of the grass } \\
\text { about } 70-80 \mathrm{~cm}\end{array}$ & $\begin{array}{l}\text { Hatched on 19.xii.03. Chick and shell pieces } \\
\text { seen at the nest. }\end{array}$ \\
\hline
\end{tabular}

\# - New breeding grounds; * - Nesting sites outside the Sanctuary. 
Table 3. Nesting site details of great Indian bustard (2003)

\begin{tabular}{|c|c|c|c|c|c|}
\hline \multirow{2}{*}{$\begin{array}{l}\text { Nest / Egg } \\
\text { (N/E) Code }\end{array}$} & \multirow[t]{2}{*}{ Nesting Site } & \multicolumn{4}{|c|}{ Distance from the Nest (mt.) } \\
\hline & & Cart track & $\begin{array}{l}\text { Seasonal } \\
\text { Stream }\end{array}$ & $\begin{array}{l}\text { Water } \\
\text { body }\end{array}$ & $\begin{array}{l}\text { Male } \\
\text { Territory }\end{array}$ \\
\hline N/E-01(03) & Alaganur Baraka (Outside the Sanctuary) & $>250$ & $>100$ (dry) & $>1500$ & $350-400$ \\
\hline N/E-02(03) & Jalakanur Baraka or Daadicherla Vagu locality (Outside the Sanctuary) & $10-15$ & $>30$ (dry) & $>2000$ & $>5000$ \\
\hline N/E-03(03) & Alaganur Baraka (Outside the Sanctuary) & $>300$ & $>150$ (dry) & $>1600$ & $400-450$ \\
\hline N/E-04(03) & Alaganur Baraka - Parumanchala crop fields. (Outside the Sanctuary) & $>250$ & $>200$ (dry) & $>2000$ & $>300$ \\
\hline N/E-05(03) & Taggu Baraka (Inside the sanctuary) & $>200$ & $>500$ (day) & $>1500$ & $>1000$ \\
\hline N/E-06(03) & Mitta Baraka (Inside the Sanctuary) & $>200$ & $>150$ (with water) & - & $250-300$ \\
\hline N/E-07(03) & Gantal Bedu (Inside the sanctuary) & $>100$ & $>50$ (with water) & - & $>2000$ \\
\hline N/E-08(03) & Gantal Bedu (Inside the sanctuary) & $>15$ & $40-50$ (with water) & - & $>2000$ \\
\hline N/E-09(03) & Taggu Baraka (Inside the Sanctuary) Close to Check Dam & $>50$ & $>15$ (with water)* $^{*}$ & - & $>1000$ \\
\hline $\mathrm{N} / \mathrm{E}-10(03)$ & Mitta Baraka (Inside the Sanctuary) & $>150$ & $>50$ (with water) & - & $300-400$ \\
\hline N/E-11(03) & Taggu Baraka (Inside the Sanctuary) Close to lure crop & $>300$ & $>200$ (with water) & $>200$ & $>2000$ \\
\hline N/E-12(03) & Pade Baraka (Inside the Sanctuary) & $20-30$ & $>10$ (with water) $^{*}$ & - & $>1000$ \\
\hline $\mathrm{N} / \mathrm{E}-13(03)$ & Bail Padu (Inside the Sanctuary) & $30-40$ & $>10$ (with water) $^{*}$ & - & $>1800$ \\
\hline N/E-14(03) & Bail Padu (Inside the sanctuary) adjoining to the Check Dam & $>150$ & $>5-7$ (with water)* & - & $>2000$ \\
\hline N/E-15(03) & Taggu Baraka(Inside the Sanctuary) & $>200$ & $>400$ (with water) & - & $>1500$ \\
\hline N/E-16(03) & Bail Padu (Inside the Sanctuary) & $30-40$ & $<10 \mathrm{~m}(\text { dry })^{*}$ & $>50$ & $>2000$ \\
\hline N/E-17(03) & Watch Tower Plot (Inside the Sanctuary) & $>40$ & $>200$ (dry) & $250-300$ & $>800$ \\
\hline N/E-18(03) & Taggu Baraka (Inside the Sanctuary) & $>200$ & $>300$ (with water) & - & $>700-800$ \\
\hline N/E-19(03) & Puppinut Chenlu (Situated between Jalakanur and Gani). & $>50$ & - & $>300$ & $>10 \mathrm{~km}$ \\
\hline N/E-20(03) & Bail Padu & $>50$ & $>150$ (with water) & $>300$ & $>1000$ \\
\hline N/E-21(03) & Gantal Bedu & $>50$ & $>250$ & $>400$ & $>1200$ \\
\hline
\end{tabular}

* - Close to the seasonal streams having very thick vegetation.

Manakadan, R. and A.R. Rahmani (1998). Crop damage by Blackbuck Antelope cervicapra at Rollapadu Wildlife Sanctuary, Andhra Pradesh. Journal of the Bombay Natural History Society 95(3): 408-417.

Rahmani, A.R. (1987). Protection of the Great Indian Bustard. Oryx 21: $174-179$

Rahmani, A.R. (1989). The Great Indian Bustard: Final Report. Bombay Natural History Society, Bombay, 234pp.

Rahmani, A.R. and R. Manakadan (1988). Bustard Sanctuaries of India: Strategies for their Conservation and Management. Technical Report No. 13. Bombay Natural History Society and U.S. Fish \& Wildlife Services, 40pp.

Thulsi Rao, K. (2002). Management Plan of Rollapadu Wildlife Sanctuary. Andhra Pradesh Forest Department, Hyderabad, 168pp.

\section{ACKNOWLedGements}

The authors are very much thankful to Sri S.K. Das IFS, Principal Chief Conservator of Forests (Administration), Sri, K.S. Rao, IFS, Principal Chief Conservator of Forests (Wildlife) \& Chief Wildlife Warden, Sri Hitesh Malhotra, IFS, Additional Principal Chief Conservator of Forests (WL), Sri A.V. Joseph, IFS, Chief Conservator of Forests (Wildlife), Andhra Pradesh and K.N. Benarji, IFS, Conservator of Forests \& Field Director, Project Tiger for constant encouragement and sustained support. We are also grateful to Dr. Rajesh Gopal, IFS, Inspector General of Forests and Director Project Tiger and the MoEF, New Delhi, for their consistent funding support and encouragement. We are very much thankful to Sri. Asad R. Rahmani, Director, Bombay Natural History Society, Mumbai, for his constant guidance in all technical matters in shaping this report without whose active cooperation and timely help, the study wouldn't have been so successful. We gratefully acknowledge our thanks to K. Naseeruddin, FRO and Y. Chakrapani, FSO, Rollapadu Wildlife Sanctuary. We acknowledge our thanks to I. Siva Rama Krishna, R.A., and V. Madhusudhan Reddy, C.O., ERM labs for GIS work and data compilation. We also gratefully acknowledge our thanks to P. Adisheshaiah and A. Gafoor, Bird watchers, Rollapadu Wildlife Sanctuary. 